\title{
PRO-EUROPEAN ORIENTATION OF UKRAINE: ADAPTATION OF THE AGRICULTURAL POLICY OF UKRAINE TO THE CONDITIONS AND REQUIREMENTS OF THE EUROPEAN UNION
}

Nadiia Davydenko ${ }^{1}$ Prof. dr hab.; Olena Lemishko ${ }^{1}$ PhD

${ }^{1}$ National University of Life and Environmental Sciences of Ukraine

\begin{abstract}
This paper provides adaptation of the agricultural policy of Ukraine to the conditions and requirements of the EU. It was revealed that sTable GDP growth of Ukraine in the period from 2014 to 2017 was provided by the agricultural sector of the economy: in 2017 its share in the formation of the country's GDP was $17 \%$. The dynamics of values and structural proportions of governmental support of agriculture was analysed, which showed that for the period of 2007 - 2017 the actual amount of financial resources aimed at implementation of governmental supportive measures of agriculture was $86.5 \%$ of the planned. The paper proves that the defining criterion for the effectiveness of state support is the sTable growth of the macroeconomic indicators of the agricultural sector. Diagnostics of the effectiveness of state support shows that the state policy instruments of the financial policy did not contribute to a sTable increase in the production of agricultural products, as the dynamics of the growth of gross agricultural production for the period of 2007 - 2017 was not stable.

In this paper the authors determined the main reasons of Ukraine's considerable lag from EU countries on social development indices in the agricultural sector. It was established that the EU experience on functioning of market socially oriented economy and state regulation of economic processes is necessary to extrapolate on functioning of agricultural sector of Ukraine. The proposed decision is to develop fundamental reforms of the State policy on development of agricultural sector of economy, to modernize the State agricultural policy and its institutional provision in accordance with the requirements of EU legislation; Economic model of agricultural sector development should be reoriented from export of raw materials on model of stimulation of the export of produced agricultural products; in the period of adaptation of agriculture of Ukraine to the requirements of EU budgetary support of agriculture must be changed from $1.0 \%$ to $3.0 \%$ of gross domestic product of the country.
\end{abstract}

Key words: the state agricultural policy; the common agricultural policy of the European Union; values and structural proportions of state support of agriculture of Ukraine.

JEL code: F36, G18, H5, Q14

\section{Introduction}

Pro-European orientation of Ukraine encourages the adaptation of the national agricultural sector of the economy to the conditions and requirements of the European Union. Priorities of the State agricultural policy aim at integration of agricultural sector of economy into European structure. The advantages of the integration consist in the creation of reliable mechanisms of economic stability, financial security and sustainable development of agriculture. Theoretical and methodological approaches of the European integration of the agricultural sector of Ukraine's economy were formed in the works of prominent Ukrainian scientists such as M. Demyanenko, Yuriy Gubenya, S. Kvasha, S. Piasetska-Ustych .

Focusing on the problems of development of Ukrainian agriculture in the context of European integration processes, Ukrainian scientists approved the necessity of systematic approach and complexity on determination of instruments of State Agricultural policy.

Studies of foreign scientist such as J. Peterson., B. Ballas, C. Pentland, M. Tracey, L. Lindbergh, J. Tinbergen have formed a significant basis of knowledge on the European integration perspectives through the development of the legal framework of European integration processes, mechanisms for its implementation and coordination of macroeconomic policy in the global economy.

At the same time in Ukraine there is No systematic research on adaptation of the Agricultural policy of Ukraine to the conditions and requirements of the European Union. The indicators of financial resources, which are aimed at realization of measures of State support of Ukrainian agriculture and their relations with the relevant EU indices, are undefined and discussed. Proceeding from the 
foregoing, the aim of the article is to analyse the European tendencies on State regulation of economic processes and identify opportunities to extrapolate them on the functioning of the agricultural sector of Ukraine.

\section{Research results and discussion}

The State agricultural policy aims to support the profitability of agricultural producers and the sTable economic situation in the industry, as well as providing security and competitive producers in the international labour division (M. Demyanenko, 2007). From the position of review of existing tendencies, consisting in state financing of the agricultural sector of Ukraine, analysis of the dynamics of values and structural proportions of state support showed that the level of financing of state supportive measures in agriculture in 2007 and 2017 were $95.9 \%$ and $92.9 \%$, that characterizes the high level of its implementation (Table 1 ).

Table 1

The dynamics of State support for agriculture of Ukraine

\begin{tabular}{|l|c|c|c|c|c|c|c|c|}
\hline \multicolumn{1}{|c|}{ Indicator } & \multicolumn{7}{c|}{ At the end of the year } \\
\cline { 2 - 8 } & $\mathbf{2 0 0 7}$ & $\mathbf{2 0 0 9}$ & $\mathbf{2 0 1 1}$ & $\mathbf{2 0 1 3}$ & $\mathbf{2 0 1 4}$ & $\mathbf{2 0 1 5}$ & $\mathbf{2 0 1 6}$ & $\mathbf{2 0 1 7}$ \\
\hline $\begin{array}{l}\text { The level of financing of } \\
\text { State agricultural } \\
\text { support, \% }\end{array}$ & 95.98 & 87.72 & 70.85 & 82.48 & 86.65 & 81.51 & 103.64 & 92.93 \\
\hline $\begin{array}{l}\text { Specific weight of state } \\
\text { budget expenditures in } \\
\text { production volume of } \\
\text { gross agricultural } \\
\text { production, \% }\end{array}$ & 4.67 & 3.17 & 3.55 & 2.92 & 2.19 & 0.89 & 0.86 & 3.60 \\
\hline $\begin{array}{l}\text { Amount of state support } \\
\text { for 1 hectare of } \\
\text { agricultural lands, UAH }\end{array}$ & 192.98 & 151.11 & 192.79 & 173.23 & 132.52 & 51.16 & 52.74 & 217.9 \\
\hline $\begin{array}{l}\text {-Budget expenditures per } \\
\text { unit of total capital (1 } \\
\text { UAH) Of agricultural } \\
\text { enterprises, UAH }\end{array}$ & 0.89 & 0.04 & 0.03 & 0.02 & 0.01 & 0.01 & 0.01 & 0.01 \\
\hline $\begin{array}{l}\text { Budget expenditures per } \\
\text { unit of net profit (1 UAH) } \\
\text { Of agricultural } \\
\text { enterprises, UAH }\end{array}$ & 0.27 & -0.44 & 0.32 & 0.48 & 0.26 & 0.02 & 0.03 & 0.13 \\
\hline
\end{tabular}

Source: author's calculations

In 2008 - 2015, the level of implementation of State supportive measures in agriculture was satisfactory $(81,5 \%-86,6 \%)$, but in $2011-2012$ the level of implementation of State supportive measures in agriculture was unsatisfactory (70.8 \% and 70.5\%). On average, for the period 2007 - 2017, the actual volume of financial resources aimed at realization of agricultural measures of state support was $86.5 \%$ from planned. In this case, according to functional classification, the share of budget financing of agriculture in the national public spending in 2017 was only $1.3 \%$. Despite a low share of the budget financing of agriculture, the steady growth of Ukraine's GDP in the period 2014 - 2017 is provided by the agricultural sector : in 2017 its share in the formation of GDP of the country was $17 \%(2014-10 \%, 2016-11.7 \%)$. Implementation of the State agricultural policy of Ukraine provides financial leverage of direct and indirect influence: budget financing, crediting, taxation, etc. The implementation of the common agricultural policy of the European Union also takes place due to the weighted tax and credit policy, but the special role is to introduce instruments for the restriction of the market self-regulation mechanism (grants, quotas, pricing tools, etc.). In fact, 85-90\% of the total amount of EU budget funding is the price support of agriculture. It should be emphasized that, despite the relatively limited contribution of agriculture in the formation of GDP of EU countries ( $2 \%-5 \%$ ), the level of financing of the common agricultural policy of the EU is 40 $45 \%$ of the European Union's budget. 
The low share of Ukraine's budget expenditures aimed at the development of agriculture leads to a chronic underfinancing of agricultural sector. Amount of state support for 1 hectare of agricultural lands in 2007 was 193 uah/1ha, in 2017 - 218gr/ha (in equivalent - 7 euro/1ga), that is, for ten years increase was only in 1.13 times (it should be noted that during this period the total area of agricultural lands decreased by 161 thousand hectares) (Table 1). State support in EU countries is from 200 to 1400 euro/ha.

The specific weight of state budget expenditures in production volume of gross agricultural production has decreased steadily - from $4.7 \%$ in 2007 to $3.6 \%$ in 2017 . However, during this period, as the positive change can be considered the change of the functional vector of state budget funds: in 2007 - 2010 financing of services, financial support of measures in the agriculture, provision of the Agricultural Fund activity and other indirect support which was $60 \%$ of budget support, respectively, the share of support of agricultural producers was only $30 \%-40 \%$. In 2017 , the financial support of agricultural producers was $77.0 \%$ of the total budget funds among which: general management and management in agriculture - $2.2 \%$; Financial support for agriculture by the reduction of loans - $5.5 \%$; Research, applied scientific developments, performance of works according to state target programs and state order - $3.0 \%$; Financial support for agriculture and industrial complex - $1.2 \%$; Organization and regulation of agricultural institutions' activities and provision of agricultural fund activity - $2.4 \%$; State support for the development of hops, the laying of young gardens, vineyards and their supervision - $5.6 \%$; State support of livestock industry $3.1 \%$; Financial support for agricultural producers - $77.0 \%$.

The defining criterion of efficiency of state support is sTable growth of macroeconomic indicators of agricultural industry. Diagnosis of the effectiveness of state support showed that the governmental financial policy leverages did not promote the sTable increase of agricultural production. Dynamics of production of gross agricultural production for the period 2007 - 2017 was not sTable (Fig. 1), respectively, the level of effectiveness of state support ranged from $(-5.63 \%)$ in 2015 to $6.93 \%$ in 2016. In 2017, this indicator was (-0.61\%). Analysis of the European model of Agriculture (Defra (2011A), Greer, Alan and Tom Hind (2012), Roederer-Rynning, Christilla (2010)) makes it possible to conclude that the priority of the common agricultural policy of the European Union is a sustainable development of the agricultural sector, solving the complex of social tasks and also active implementation of nature-protection measures.

Ukraine is far behind the EU countries on social development indicators in the agricultural sector of the economy. The primary causes of such lag are: insufficient institutional provision of state policy on sustainable agricultural development, including rural areas; lack of necessary funding sources; non-balance of coordination mechanism and proper monitoring of the use of budget funds, aimed at social development of the villages, etc.

Taking into account that Ukraine concerning natural-climatic conditions and soil quality belongs to one of the most favourable agricultural country among European countries (S. Piasetska-Ustych, 2016), the urgent issue is the problem of state provision for creation in Ukraine the adaptive agroecosystem. 


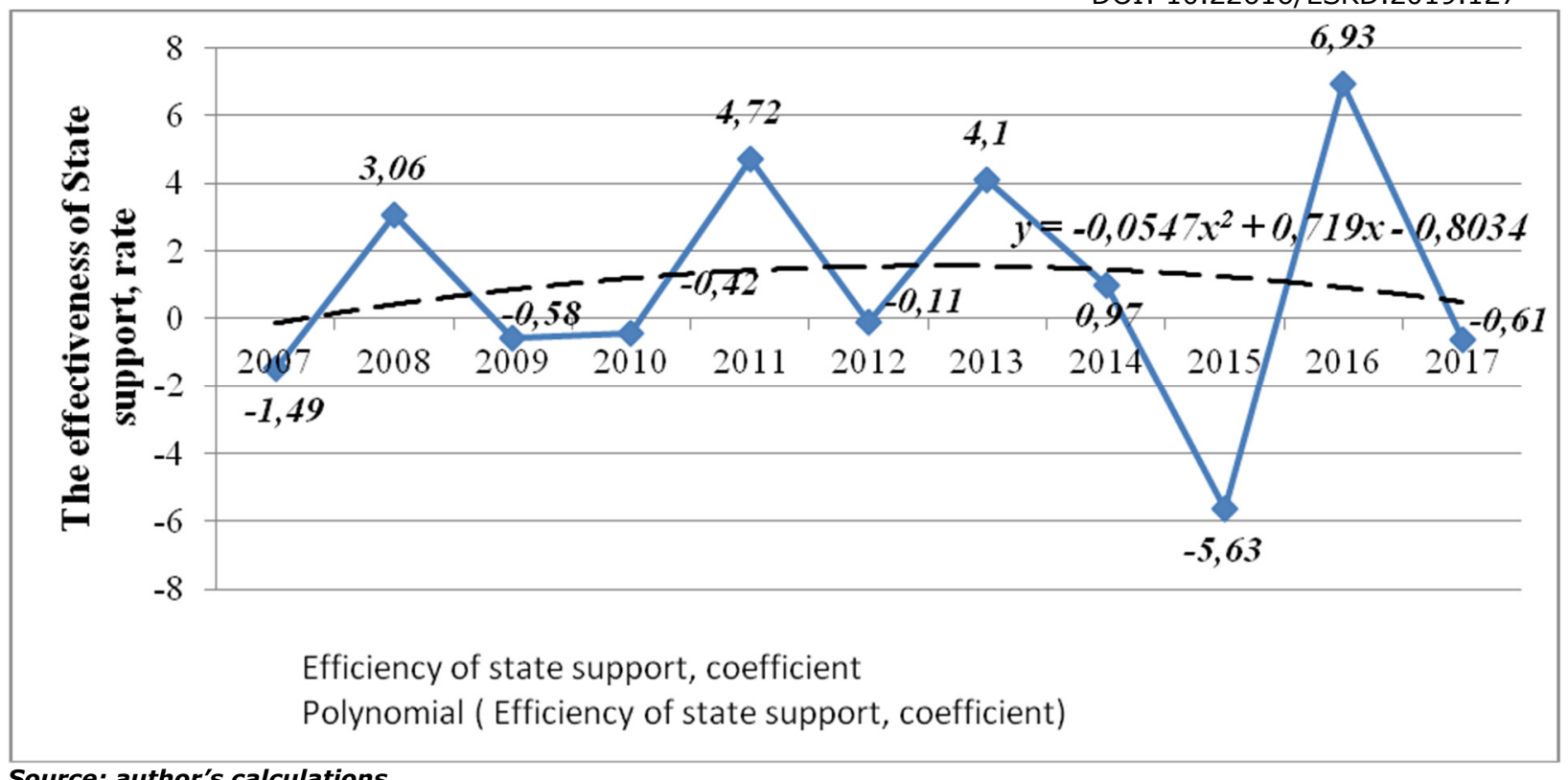

Source: author's calculations

Fig. 1. The effectiveness of state support of agriculture of Ukraine (approximation-polynomial second degree)

Adaptation of the national agricultural sector of the economy to the conditions and requirements of the EU is subordinated to the strategy of creating a reliable partnership between the EU and Ukraine in the trade in agricultural and food products. According to the economical results of 2016, the EU countries took second place in the regional structure of agricultural production: foreign trade turnover between Ukraine and EU countries was \$6 182.9 million, from which Ukrainian products export-\$4 242.4 million. In this case, the key export products were: cereals - \$1 279.5 million; Oi I-\$1, 185 million; Oil-bearing crop seeds-\$587.5 million. Import of agricultural and food products from the EU countries to Ukraine $-\$ 1940.5$ million. This tendency is extremely important not only for Ukraine, being a state oriented on export of agricultural products, and also for the European Union in the context of raising its status on the global market.

\section{Conclusions, proposals, recommendations}

Adaptation of the state agricultural policy of Ukraine to the conditions and requirements of the EU subordinated to the search of the totality of methodological principles, forms and methods of State support for the improvement of agricultural efficiency in the simultaneous promotion of sustainable development in the countryside, and preserving the ecological agricultural potential, in accordance with EU standards. The European model of agriculture has proved to be productive both in economic and social direction. EU experience on functioning of market socially oriented economy and state regulation of economic processes is necessary to extrapolate on functioning of agricultural sector of Ukraine. We believe that it is necessary: firstly, to develop fundamental reforms of the state policy on development of agricultural sector, to implement a set of state measures that ensure effective functioning of finance and financial system; modernize the state agricultural policy and its institutional support in accordance with the requirements of EU legislation; secondly, the economic model of agricultural sector development should be reoriented from export of raw materials on model of stimulation of the export of produced agricultural products; and thirdly, in the period of adaptation of Ukrainian agriculture to European Union requirements, budgetary support of agriculture should increase from $1.0 \%$ to $3.0 \%$ of gross domestic product of the country. The basis of European implementation of Ukraine should be a socially oriented market economy. The key 
requirement in this direction is to develop conceptual approaches for financial influence on value and structural proportions of agricultural functioning. That actualizes the need for further research related to the development and implementation of the state aricultural policy and the development of modern and sustainable agricultural production in accordance with EU standards.

\section{Bibliography}

1. Balassa, B. (1961). The Theory of Economic Integration. London.

2. DEFRA (2011a) CAP Reform post 2013: Defra Discussion Paper on the Impact in England of the EU Commission Regulatory Proposals for the Common Agricultural Policy Reform, post 2013. December 2011.

3. Demyanenko, M. 2007. Financial Problems of the Formation and Development of the Agrarian Market, Economics of Agroindustrial Complex. 5, pp.4-18.

4. Greer, A. and Hind, T. (2012) The Lisbon Treaty, Agricultural Decision-making and the Reform of the CAP: An Analysis of the Nature and Impact of Co-decision, Politics and Society 31 (4):pp. 331-41.

5. Hubeni, Yu. (2002). Agrarian Reform in the Czech Republic: From the "Velvet Revolution" to European Integration. An Example Worthy of Imitation. Lviv, Ukr. Technologies.

6. Kvasha S. M. The European direction - in Figures and facts - [Electronic resource]. - Access mode: http://agro-business.com.ua

7. Lemishko, O. (2018). Philosophical Methodology in Research of Capital Reproduction Financial Policy, Scientific Bulletin Polesie. 2 (14). pp. 121-128.

8. Lindberg, L. N. (1970). Europe's Would-be Polity. Patterns of Change in the European Community. Englewood Cliffs, Prentice Hall.

9. Pentland, C. (1973). International Theory and European Integration. London, Faber\&Faber Ltd.

10. Peterson, J. (1995). Decision-making in the European Union: Towards a Framework for Analysis. Journal of European Public Policy 2(1): pp. 69-93.

11. Pyasetsky-Ustich, S. (2016). Genesis of the Common Agricultural Policy of the EU: Perspectives and Risks for Ukraine, Scientific Bulletin of the International Humanitarian University. Series: Economics and Management. 16. pp. 23-28.

12. Roederer-Rynning, C. (2010) The Common Agricultural Policy: the Fortress Challenged, in Helen Wallace, Mark Pollack and Alastair Young (Eds.), Policy-Making in the European Union (6th ed.). Oxford: Oxford University Press, pp. 181-206.

13. State Statistics Service of Ukraine - [Electronic resource]. - Access mode: http://www.ukrstat.gov.ua

14. Tracy, M. (1995). Agriculture and Food in the Economies of Developed Countries: an Introduction to Theory, Practice and Politics. SPb, School of Economics

15.Zinchuk, T. (2008). European Integration: Problems of Adaptation of the Agrarian Sector of the Economy. Zhitomir: State University "State. agroecol un-t". 